\title{
Clinical Biochemistry, Haematology and Body Weight in Piglets
}

\author{
By A.K. Egeli ${ }^{1}$, T. Framstad ${ }^{1}$ and H. Morberg ${ }^{2}$ \\ ${ }^{1}$ Department of Reproduction and Forensic Medicine and ${ }^{2}$ Department of Biochemistry, Physiology and Nutri- \\ tion, Central Laboratory, Norwegian College of Veterinary Medicine, Oslo Norway.
}

\begin{abstract}
Egeli AK, Framstad T, Morberg H: Clinical biochemistry, haematology and body weight in piglets. Acta vet. scand. 1998, 39, 381-393. - Reference ranges for clinical biochemical parameters commonly investigated in pigs were determined in one- (day 1), 21- and 35-day old piglets. The mean and standard deviation were also estimated for body weight, and haematological and clinical biochemical parameters at these ages. The piglets were divided into 2 investigation groups according to whether they had a haemoglobin concentration $\leq 80 \mathrm{~g} / 1$ ("anaemic group") or $>80 \mathrm{~g} / \mathrm{l}$ ("normal group") on days 14, 21 and 28. The "anaemic group" was compared to the "normal group" on days 21 and 35. Many of the clinical biochemical parameters varied according to age. Some of the enzymes had high average values and wide reference ranges in piglets, especially on day 1, compared to the reference ranges for sows given in the literature. The reference ranges for some of the metabolic parameters were broader on day 1 than later in the preweaning period. The reference ranges for albumin, total iron-binding capacity and serum iron were, however, lower and more narrow on day 1 . On days 21 and 35, relatively high values for phosphorus must be considered "normal" compared to the figures given in the literature for adult pigs. The other minerals seemed to be quite unaffected of age, but some were affected by anaemia. The anaemic piglets had lower average serum iron but higher total iron-binding capacity than the "normal" piglets on days 21 and 35 . However, variation between piglets gave wide reference ranges, indicating that these parameters will only have limited usefulness in detecting iron deficiency anaemia in piglets. The electrolytes seemed also to be affected by the existence of anaemia. The body weight and leukocyte counts were significantly lower in the "anaemic group" than the "normal group" on day 35 , while the greatest differences in clinical biochemical parameters between the groups were found on day 21 , when the piglets in the "anaemic group" were most severely anaemic. Although these piglets suffered from severe iron-deficiency anaemia, only a few clinical biochemical parameters were affected, and the differences between groups were mostly small.
\end{abstract}

anaemia; reference ranges; wood chemistry; blood values.

\section{Introduction}

Normal values in clinical biochemistry may vary with a number of factors, including diet, housing, season, age, stage of pregnancy, lactation phase, breed and sex (Wilson et al. 1972, Tewes et al. 1979, Groth et al. 1986, Framstad et al. 1991). Differences in sampling and anal- ysis procedures may also affect the results (Tumbleson et al. 1986, Framstad et al. 1989). Most of the literature concerning clinical biochemistry in pigs has concerned sows during pregnancy and lactation, and growing pigs (Reese et al. 1984, Friendship et al. 1984, 
Kaneko 1989, Framstad et al. 1991). Information on new-born and suckling piglets is sparse. Knowledge of clinical biochemistry in suckling piglets is probably not of great importance in ordinary veterinary practice, but may be useful when piglets are used for research. Most of the available studies on clinical biochemistry in piglets address only a few parameters or a restricted time frame (Ullrey et al. 1967, Tumbleson et al. 1972, Brenner \& Gürtler 1977, Glawischnig et al. 1977), the most commonly investigated parameters being minerals, glucose and proteins.

Unless piglets are given iron supplements, they become anaemic a few days after birth (Furugouri 1975). This may interfere with clinical biochemistry. In haematology, numerous studies have been performed to evaluate the effect of iron treatment. The reference ranges for haematological parameters in piglets are very difficult to estimate because they vary with iron treatment.

The aim of the present study was to obtain a general picture of reference ranges for common biochemical parameters in "normal" and "anaemic" piglets during the nursing period. The mean and standard deviations for body weight and different haematological and clinical biochemical parameters of the piglets were also estimated.

\section{Materials and methods}

This trial was carried out on the Norwegian College of Veterinary Medicine's research farm. Piglets from 19 sows of the Norwegian Landrace breed were available for the study. The sows were fed pelletted feed at a level of $2.2+0.5$ feed units per piglet (Optimat 3 with enzymes $\left.{ }^{\circledR}\right)$ per day. The piglets were kept with the sows in farrowing crates on a concrete floor. Besides suckling the sows, the piglets were fed pelleted food (Format Kvikk ${ }^{\circledR}$ ) from 7 days of age. Feed composition (as declared) is shown in
Table 1. The male piglets were not castrated during the study, and no routine medical treatment was given. All piglets were individually tattooed with a number in the ear.

On the morning of day 1 , i.e. $24 \pm 12 \mathrm{~h}$ after birth, the piglets were weighed and blood sampled before being divided into 2 treatment groups. Half of the piglets (split litters) were injected subcutanously in the inguinal area with $180 \mathrm{mg}$ iron as iron-dextran $\left(\right.$ Idofer $\left.^{\circledR}\right)$. All piglets had on average access to 2-3 $\mathrm{g}$ amino acid-chelated iron (Bioplex ${ }^{\circledR}$ ) (about $50 \mathrm{mg}$ iron) daily from day 1 . The piglets were also weighed and bled in the morning on days 7,14 , 21, 28 and 35.

The day 1 data from all the piglets which were healthy at birth, and which survived to weaning at 5 weeks were included in the study $(n=133)$. On days 21 and 35 the piglets were divided into 2 investigation groups according to whether they were considered anaemic or not. The piglets in the "anaemic group" were included on the basis that they had a haemoglobin concentration of $\leq 80 \mathrm{~g} / 1$ on days 14,21 and 28 , and had not been injected with iron-dextran $(n=42)$. The piglets in the "normal group" were included on the basis that they had a haemoglobin concentration of $>80 \mathrm{~g} / 1$ on days 14,21 and 28 and had been injected with irondextran as previously described $(n=60)$. In addition, only piglets which were clinically healthy on days 21 and 35 were included. The decrease in number of piglets from day 1 to day 21 and 35 was mainly due to the fact that the not included piglets did not fulfil the criteria of a haemoglobin concentration of $>$ or $<80 \mathrm{~g} / \mathrm{l}$ over a prolonged period. The number of males and females in each group was nearly the same. One $\mathrm{ml}$ blood designated for haematological analysis was collected in tubes containing ethylene diaminetetra-acetic acid (EDTA) as an anticoagulant, and $2 \mathrm{ml}$ blood designated for clinical biochemistry was collected in plain tubes by the 
method earlier described (Framstad et al. 1988).

Blood samples collected for haematology at week-ends were stored in a refrigerator until Monday morning, although most of the samples were analysed on the same day as collected. The plain tubes for clinical biochemistry were centrifuged within $2 \mathrm{~h}$ at $3000 \mathrm{rpm}$. for 10 min, the serum being kept at $-20^{\circ} \mathrm{C}$ until analysis. The laboratory performing the analyses participates in the Norwegian quality control programmes, organised by Labquality (Finland), for clinical chemical and haematological analyses.

The haemoglobin concentration (HGB), erythrocyte count (RBC), mean cell volume (MCV), erythrocyte distribution width (RDW) and haemoglobin distribution width (HDW), as well as the number of leukocytes (WBC), neutrophilic granulocytes (NEUT), lymphocytes (LYMP), monocytes (MONO), eosinophilic granulocytes (EOS), basophilic granulocytes (BASO) and large unstained cells (LUC), were measured using an automated blood analyser; Technicon $\mathrm{H}^{*}{ }^{\circledR}$ (Technicon Instrument Corp, Tarrytown, NY). Haematocrit (HCT), mean cell haemoglobin $(\mathrm{MCH})$ and mean cell haemoglobin concentration (MCHC) were estimated by the Technicon $\mathrm{H}^{*} 1^{\circledR}$ from RBC and $\mathrm{MCV}$ in HCT, RBC and HGB in $\mathrm{MCH}$, and $\mathrm{RBC}, \mathrm{HGB}$ and MCV in MCHC.

The serum was analysed on days 1,21 and 35 by an automated Technicon Axon ${ }^{\circledR}$ (Technicon Instrument Corp, Tarrytown, NY) analyser for aspartate aminotransferase (AST), alanine aminotransferase (ALT), alkaline phosphatase (AP), creatine kinase (CK), lactate dehydrogenase (LD), gamma glutamyltransferase (GGT), glutamate dehydrogenase (GD), total protein (TP), albumin (Alb), urea, creatinine (Creat), total bilirubin, (TB), cholesterol (Chol), triglyserides (Trig), free fatty acid (FFA), glucose (Glu), phosphorus $(\mathrm{P})$, calcium $(\mathrm{Ca})$, magne-
Table 1. The composition of pellet feed fed to, respectively, sows (Optimat 3 with enxymes ${ }^{\circledR}$ ) and piglets (Format kvikk ${ }^{\circledR}$ ).

\begin{tabular}{|c|c|c|}
\hline & $\begin{array}{l}\text { Optimat } 3 \text { with } \\
\text { with enzymes }\end{array}$ & Format kvikk \\
\hline Feed units $/ 100 \mathrm{~kg}$ & 96.0 & 114.4 \\
\hline Protein (\%) & 15.5 & 16.7 \\
\hline Fat (\%) & 4.3 & 5.9 \\
\hline Ash (\%) & 4.7 & 5.0 \\
\hline Fibre (\%) & 6.1 & 3.3 \\
\hline $\mathrm{Ca}(\%)$ & 0.89 & 0.81 \\
\hline $\mathrm{P}(\%)$ & 0.72 & 0.68 \\
\hline $\mathrm{Na}(\%)$ & 0.20 & 0.17 \\
\hline $\mathrm{Cu}(\mathrm{mg} / \mathrm{kg})$ & 15 & 20 \\
\hline $\mathrm{Se}(\mathrm{mg} / \mathrm{kg})$ & 0.3 & 0.4 \\
\hline $\mathrm{Fe}(\mathrm{mg} / \mathrm{kg})$ & 75 & 200 \\
\hline $\mathrm{Zn}(\mathrm{mg} / \mathrm{kg})$ & 105 & 140 \\
\hline $\mathrm{Mn}(\mathrm{mg} / \mathrm{kg})$ & 60 & 80 \\
\hline I (mg/kg) & 0.75 & 1 \\
\hline
\end{tabular}

The pellet feed also contained added vitamins.

sium $(\mathrm{Mg})$, sodium $(\mathrm{Na})$, potassium $(\mathrm{K})$, chloride $(\mathrm{Cl})$, serum iron $(\mathrm{Fe})$ and total iron-binding capacity (TIBC). The methods are shown in Table 2 , and the analyses were performed at $37^{\circ} \mathrm{C}$. The control sera were Testpoint 1 and $2^{\circledR}$ ("Bayer"), Seronorm ${ }^{\circledR}$ ("Nycomed"), Seronorm lipid ${ }^{\circledR}$ ("Nycomed") and Precinom $E^{\circledR}$ ("Boehringer Mannheim").

The number of piglets (n) varied somewhat between the parameters because of too little serum to perform the analyses in some cases, and, in others, because of haemolysis, coagulation or lipaemia which might have interfered with the results.

When results were found to show a Gaussian distribution according to Shapiro-Wilk's test at a significance level of $5 \%$, the reference range includes the values within 1.96 standard deviations (SD) from the mean (Mean $\pm 1.96 \mathrm{SD}$ ). Non Gaussian-distributed data were logarithmically transformed, and if then found to show a Gaussian distribution, values within Mean \pm $1.96 \mathrm{SD}$ were included in the reference ranges. 
Table 2. Methods in clinical biochemical analysis.

\begin{tabular}{llll}
\hline & Method & Reaction Type & Manufacturer \\
\hline AST & IFCC w.o./P5P (2 reagent) & Zero-order kinetic & "Bayer" \\
ALT & IFCC w.o./P5P (2 reagent) & Zero-order kinetic & "Bayer" \\
AP & SCE, DEA buffer & Zero-order kinetic & "Bayer" \\
CK & IFCC, NAC activated (1 reagent) & Zero-order kinetic & "Bayer" \\
LD & SCE, P $\rightarrow$ L, 340 nm TRIS & Zero-order kinetic & "Bayer" \\
GGT & SCE (Szasz) & Zero-order kinetic & "Bayer" \\
GD & "Optimized standard method" & Zero-order kinetic & "Boehringer \\
& (conforming to the recommendations of DGKC) & & Mannheim" \\
TP & Biuret & Endpoint & "Bayer" \\
Alb & BCG dyr-binding w/rapid absorbance & Endpoint & "Bayer" \\
Urea & Urease w/GLDH & First-order kinetic & "Bayer" \\
Creat & Jaffé, alkaline picrate & First-order kinetic & "Bayer" \\
TB & Blanked diazo & Endpoint, blanked & "Bayer" \\
Chol & Enzymatic, Trinder 525 nm & Endpoint & "Bayer" \\
Trig & GPO, Trinder w.o./serum blank & Endpoint & "Bayer" \\
FFA & Enzymatic 550 nm (Method: ACS-ACOD-MEHA) & Endpoint & "Wako" \\
Glu & Hexokinase, 340 nm & Endpoint & "Bayer" \\
P & Phosphomolybdate, 340 nm & Endpoint & "Bayer" \\
Ca & Cresolphtalein complexone & Endpoint & "Bayer" \\
Mg & Enzymatic uv method & Endpoint & "Bayer" \\
& & & (SERA-PAK) \\
Na & ISE, diluted & Potentiometric & "Bayer" \\
K & ISE, diluted & Potentiometric & "Bayer" \\
Cl & Ferric thiocyanate & Endpoint & "DCL" \\
Fe & w.o./deproteinization-w/Ferrozine ${ }^{\circledR}$ & Endpoint & "bioMérieux" \\
TIBC & Saturation of transferrin and adsorption of & Endpoint & "bioMérieux" \\
& excess iron. Determination of iron is then & & \\
& performed using the same kit. & & \\
\hline
\end{tabular}

The analyses were performed at $37^{\circ} \mathrm{C}$.

Measurements which still failed to show a Gaussian distribution are given as percentiles. The reference limits given are the 2.5 th and 97.5th percentiles, and also the 10th and 90th percentiles. Comparison of 2 means between the groups on days 21 and 35 was done using the $t$-test.

\section{Results}

The differences between anaemic and "normal" piglets in haematological parameters, except MCHC estimated by the Technicon $\mathrm{H}^{*} 1$, were as excepted (Table 3 ). The anaemic piglets had lower weight $(\mathrm{p}<0.05), \mathrm{WBC}(\mathrm{p}<0.01)$, NEUT $(p<0.001)$ and $\operatorname{EOS}(p<0.01)$ on day 35 than the "normal piglets" (Table 3). Serum Fe and TIBC were low at birth, and serum $\mathrm{Fe}$ was lower and TIBC higher in anaemic than in "normal" piglets on days 21 and 35 (Table 4). AST, ALT, $\mathrm{AP}$ and $\mathrm{LD}$ were lower in the anaemic piglets than the "normal" piglets on day 21 . The electrolytes $\mathrm{Na}$ and $\mathrm{CL}$ were also lowest in the anaemic piglets compared to the «normal» on day 21 (Table 4). Reference ranges in clinical biochemistry for anaemic and "normal" piglets are given in Table 5. 
Table 3. Body weight and haematological parameters in piglets the day after birth (Day 1), and in one group of anaemic and one group of normal piglets on days 21 and 35 (Mean \pm SD).

\begin{tabular}{|c|c|c|c|c|c|c|c|c|c|c|}
\hline \multirow[b]{2}{*}{ Weight (kg) } & \multicolumn{2}{|c|}{$\begin{array}{l}\text { Day } 1 \\
n=133\end{array}$} & \multicolumn{2}{|c|}{$\begin{array}{l}\text { Day } 21 \\
\text { Normal piglets } \\
\mathrm{n}=60\end{array}$} & \multicolumn{2}{|c|}{$\begin{array}{l}\text { Day } 21 \\
\text { Anaemic piglets } \\
n=42\end{array}$} & \multicolumn{2}{|c|}{$\begin{array}{l}\text { Day } 35 \\
\text { Normal piglets } \\
n=60\end{array}$} & \multicolumn{2}{|c|}{$\begin{array}{l}\text { Day } 35 \\
\text { Anaemic piglets } \\
n=42\end{array}$} \\
\hline & 1.79 & $(0.38)$ & 7.27 & $(1.91)$ & 6.78 & $(1.54)$ & 12.20 & (3.18) & 10.73 & $(2.51)^{*}$ \\
\hline $\operatorname{HGB}(g / 1)$ & 81 & (10) & 102 & (10) & 47 & $(10)^{* * *}$ & 101 & (10) & 66 & $(22)^{* * *}$ \\
\hline $\mathrm{RBC}\left(\times 10^{12} / 1\right)$ & 3.85 & $(0.65)$ & 5.35 & $(0.50)$ & 2.93 & $(0.80)^{* * *}$ & 5.79 & $(0.68)$ & 4.41 & $(1.58)^{* * *}$ \\
\hline $\operatorname{MCV}(f)$ & 69.4 & (6.6) & 63.6 & (6.4) & 46.8 & $(7.8)^{* * *}$ & 56.5 & $(6.6)$ & 44.8 & $(6.5)^{* * *}$ \\
\hline RDW (\%) & 18.4 & & 20.3 & & $35.1^{*}$ & & 20.6 & & $33.1^{* *}$ & \\
\hline HDW (g/l) & 33.4 & & 25.1 & & $35.8^{*}$ & & 22.3 & & $29.5^{*}$ & \\
\hline HCT (1/1) & 0.26 & $(0.04)$ & 0.34 & $(0.03)$ & 0.14 & $(0.05)^{* * *}$ & 0.32 & $(0.03)$ & 0.21 & $(0.08)^{* * *}$ \\
\hline $\mathrm{MCH}(\mathrm{pg})$ & 21.2 & (2.0) & 19.2 & (1.9) & 16.5 & $(2.0)^{* * *}$ & 17.6 & (2.1) & 15.5 & $(2.3)^{* * *}$ \\
\hline $\mathrm{MCHC}(\mathrm{g} / \mathrm{l})$ & 306 & (13) & 302 & (9) & 361 & $(77)^{* * *}$ & 311 & (10) & 336 & $(61)^{* *}$ \\
\hline WBC (x109/1) & 9.07 & $(4.23)$ & 8.40 & $(3.38)$ & 8.47 & (3.11) & 13.58 & (3.94) & 11.25 & $(3.24)^{* *}$ \\
\hline NEUT $\left(x 10^{9} / 1\right)$ & 6.56 & (3.90) & 3.08 & (1.72) & 2.68 & (1.61) & 5.56 & $(2.94)$ & 3.73 & $(1.56)^{* * *}$ \\
\hline LYMP (x109/1) & 1.77 & $(0.61)$ & 4.57 & $(2.53)$ & 5.02 & (2.33) & 6.78 & (2.19) & 6.51 & $(2.47)$ \\
\hline MONO (x109/1) & 0.36 & $(1.13)$ & 0.19 & $(0.10)$ & 0.21 & $(0.12)$ & 0.21 & $(0.10)$ & 0.20 & $(0.10)$ \\
\hline $\operatorname{EOS}\left(x 10^{9} / 1\right)$ & 0.08 & $(0.05)$ & 0.14 & $(0.13)$ & 0.09 & $(0.10)$ & 0.20 & $(0.14)$ & 0.12 & $(0.08)^{* *}$ \\
\hline BASO $\left(\times 10^{9} / 1\right)$ & 0.03 & $(0.03)$ & 0.08 & $(0.11)$ & 0.05 & $(0.04)$ & 0.12 & $(0.12)$ & 0.10 & $(0.17)$ \\
\hline LUC $\left(\times 10^{9} / 1\right)$ & 0.27 & $(0.13)$ & 0.38 & $(0.22)$ & 0.42 & $(0.22)$ & 0.72 & $(0.31)$ & 0.64 & $(0.25)$ \\
\hline
\end{tabular}

SD in parentheses. ${ }^{*}=\mathrm{p}<0.05, * *=p<0.01, * * *=p<0.001$ between groups on the same day.

\section{Discussion}

The clinical biochemical parameters evaluated in piglets in the present study were parameters which are normally investigated in clinical biochemistry in adult pigs, i.e. concerning organ profiles, minerals and electrolytes, and fat, carbohydrate and protein metabolism. Only piglets considered suitable for research purposes were included, i.e. survived to weaning and with no history of serious disease. The piglets which joined the "normal group" were raised under conditions usual in many countries, and the reference ranges should therefore be representative for piglets in general.

One of the aims of the study was to investigate whether iron deficiency has any effect on clinical biochemistry. The anaemic limit, i.e. the point when the anaemia begins to exert a detrimental effect on weight gain or gives rise to clinical symptoms of anaemia, is by most authors set at a haemoglobin concentration of 80 g/l (Agricultural Research Council 1967, Baustad 1969, Furugouri 1975, van Kempen 1987). Anaemia over a period probably has an even more severe effect on performance. The piglets which joined the "anaemic group" were anaemic for at least the first 4 weeks of life. At weaning, although some of these piglets had achieved normal haemoglobin concentrations, probably because of higher consumption of pelleted food during the last week of the preweaning period, they had nevertheless suffered from anaemia over a prolonged period. The haematological values in the "anaemic group" strongly indicated a severe iron deficiency anaemia on day 21 , and a more moderate anaemia on day 35 . Iron-deficiency anaemia is generally accepted to be hypochromic. Nevertheless MCHC was higher in the "anaemic" than in the "normal group" in the present study, when estimated by the Technicon $\mathrm{H}^{*} 1$. However, $\mathrm{MCH}$, which was also estimated, was, as expected, 
Table 4. Clinical biochemical parameters in piglets the day after birth (Day 1), and in one group of anaemic and one group of normal piglets on days 21 and 35 (Mean $\pm \mathrm{SD}$ ).

\begin{tabular}{|c|c|c|c|c|c|c|c|c|c|c|}
\hline \multirow[b]{2}{*}{ AST (U/l) } & \multicolumn{2}{|c|}{$\begin{array}{l}\text { Day } 1 \\
n=133\end{array}$} & \multicolumn{2}{|c|}{$\begin{array}{l}\text { Day } 21 \\
\text { Normal piglets } \\
n=60\end{array}$} & \multicolumn{2}{|c|}{$\begin{array}{l}\text { Day } 21 \\
\text { Anaemic piglets } \\
n=42\end{array}$} & \multicolumn{2}{|c|}{$\begin{array}{l}\text { Day } 35 \\
\text { Normal piglets } \\
\mathrm{n}=60\end{array}$} & \multicolumn{2}{|c|}{$\begin{array}{l}\text { Day } 35 \\
\text { Anaemic piglets } \\
n=42\end{array}$} \\
\hline & 103 & (49) & 29 & (10) & 21 & $(8)^{* * *}$ & 32 & (14) & 28 & (19) \\
\hline $\operatorname{ALT}(\mathrm{U} / \mathrm{l})$ & 51 & (15) & 28 & (10) & 23 & $(6)^{* *}$ & 39 & $(20)$ & 31 & $(11)^{*}$ \\
\hline $\mathrm{AP}(\mathrm{U} / \mathrm{l})$ & 4193 & (1328) & 1290 & $(517)$ & 1036 & $(388)^{* *}$ & 824 & (296) & 841 & $(284)$ \\
\hline CK (U/l) & 639 & $(633)$ & 379 & (339) & 395 & (333) & 659 & (778) & 520 & $(572)$ \\
\hline $\mathrm{LD}(\mathrm{U} / \mathrm{l})$ & 1567 & $(565)$ & 1236 & (295) & 956 & $(243)^{* * *}$ & 1207 & (353) & 1084 & (296) \\
\hline GGT (U/l) & 65 & (27) & 36 & (11) & 35 & (12) & 29 & (7) & 30 & (7) \\
\hline GD (U/l) & 7 & (6) & 5 & (8) & 5 & (11) & 2 & (3) & 2 & (3) \\
\hline $\mathrm{TP}(\mathrm{g} / \mathrm{l})$ & 54 & (12) & 52 & (7) & 55 & $(6)^{*}$ & 48 & (8) & 52 & $(8)^{*}$ \\
\hline Alb (g/l) & 11 & (2) & 32 & (4) & 33 & (3) & 30 & (5) & 32 & $(5)^{*}$ \\
\hline Urea $(\mathrm{mmol} / \mathrm{l})$ & 5.7 & (2.4) & 2.0 & $(1.0)$ & 2.7 & $(1.1)^{* * *}$ & 2.1 & $(0.8)$ & 2.5 & (1.5) \\
\hline Creat $(\mu \mathrm{mol} / \mathrm{l})$ & 70 & (12) & 87 & (12) & 81 & $(10)^{* *}$ & 92 & (11) & 88 & (12) \\
\hline TB $(\mu \mathrm{mol} / 1)$ & 6 & (4) & 4 & (2) & 4 & (2) & 2 & (2) & 3 & (3) \\
\hline Chol (mmol/l) & 1.9 & $(0.6)$ & 3.8 & $(1.2)$ & 3.7 & (1.1) & 3.0 & $(0.7)$ & 3.3 & $(1.0)$ \\
\hline Trig (mmol/l) & 1.3 & $(1.0)$ & 1.1 & $(0.5)$ & 0.9 & $(0.4)^{*}$ & 0.9 & $(0.6)$ & 0.8 & $(0.4)$ \\
\hline FFA (mmol/l) & 0.5 & $(0.2)$ & 0.5 & $(0.3)$ & 0.5 & $(0.2)$ & 0.4 & $(0.3)$ & 0.3 & $(0.2)$ \\
\hline Glu (mmol/1) & 5.0 & $(1.2)$ & 6.8 & $(0.6)$ & 6.7 & $(0.9)$ & 6.7 & $(0.8)$ & 6.6 & $(1.0)$ \\
\hline $\mathrm{P}(\mathrm{mmol} / \mathrm{l})$ & 2.0 & $(0.6)$ & 3.4 & $(0.4)$ & 3.2 & $(0.4)$ & 3.3 & $(0.3)$ & 3.2 & $(0.4)$ \\
\hline $\mathrm{Ca}(\mathrm{mmol} / \mathrm{l})$ & 2.7 & $(0.2)$ & 2.9 & $(0.2)$ & 2.9 & $(0.2)$ & 2.8 & $(0.2)$ & 2.8 & $(0.2)$ \\
\hline $\mathrm{Mg}(\mathrm{mmol} / \mathrm{l})$ & 0.81 & $(0.11)$ & 0.98 & $(0.15)$ & 0.93 & $(0.13)$ & 0.84 & $(0.12)$ & 0.91 & $(0.12)^{* *}$ \\
\hline $\mathrm{Na}(\mathrm{mmol} / \mathrm{l})$ & 139 & (7) & 143 & (6) & 137 & $(6)^{* * *}$ & 143 & (4) & 141 & $(6)^{* *}$ \\
\hline $\mathrm{K}(\mathrm{mmol} / \mathrm{l})$ & 4.1 & $(0.8)$ & 4.4 & $(0.5)$ & 4.6 & $(0.5)$ & 4.3 & $(0.4)$ & 4.5 & $(0.6)$ \\
\hline $\mathrm{Cl}(\mathrm{mmol} / \mathrm{l})$ & 107 & (6) & 109 & (7) & 105 & $(6)^{* *}$ & 107 & (5) & 106 & (4) \\
\hline $\mathrm{Fe}(\mu \mathrm{mol} / \mathrm{l})$ & 9 & (5) & 33 & (22) & 9 & $(10)^{* * *}$ & 32 & (18) & 23 & $(19)^{*}$ \\
\hline TIBC $(\mu \mathrm{mol} / \mathrm{l})$ & 33 & (11) & 94 & (21) & 146 & $(21)^{* * *}$ & 92 & (25) & 127 & $(27)^{* * *}$ \\
\hline
\end{tabular}

SD in parentheses. $*=p<0.05, * *=p<0.01, * * *=p<0.001$ between groups on the same day.

lowest in the "anaemic group". MCV, as measured by the Technicon $\mathrm{H}^{*}$, was also lowest in the "anaemic group". RDW and HDW were both higher in the "anaemic" than in the "normal group", which was as expected from the results of earlier studies performed by the authors Egeli \& Framstad 1998a and b.

Gainer et al. (1985) found depletion of the neutrophil count in iron-deficiency anaemic piglets. A lower WBC, caused by a lower neutrophil counts, was also found in the present study on day 35 in the anaemic piglets compared to the normal piglets. The eosinophils were also lower in the "anaemic group" than in the "normal group" at this time. A lowering of the neutrophil count in the anaemic piglets may increase their susceptibility to infection. The clinical significance of lowered eosinophil counts is more uncertain.

The data used for determining the reference ranges for clinical biochemical parameters were first investigated for Gaussian distribution, either directly or logarithmically transformed. If they were found to show a Gaussian distribution, the standard procedure for determining reference boundaries of applying the Mean \pm 1.96 SD was used (Farver 1989). The commonly used method of applying the 97.5 th and 2.5th percentiles (Farver 1989) was employed for non-Gaussian distributed data. Pro- 
Table 5. Reference ranges for clinical biochemical parameters in piglets the day after birth (Day 1), and in one group of anaemic and one group of normal piglets on days 21 and 35 .

\begin{tabular}{|c|c|c|c|c|c|}
\hline & $\begin{array}{l}\text { Day } 1 \\
n=133\end{array}$ & $\begin{array}{l}\text { Day } 21 \\
\text { Normal piglets } \\
\mathrm{n}=60\end{array}$ & $\begin{array}{l}\text { Day } 21 \\
\text { Anaemic piglets } \\
n=42\end{array}$ & $\begin{array}{l}\text { Day } 35 \\
\text { Normal piglets } \\
n=60\end{array}$ & $\begin{array}{l}\text { Day } 35 \\
\text { Anaemic piglets } \\
\mathrm{n}=42\end{array}$ \\
\hline $\operatorname{AST}(\mathrm{U} / \mathrm{l})$ & $36-236 \mathrm{~b}$ & $14-52 \mathrm{~b}$ & $6-36 a$ & $\begin{array}{l}8-84 \mathrm{c} \\
18-44 \mathrm{~d}\end{array}$ & $\begin{array}{l}14-125 \mathrm{c} \\
14-42 \mathrm{~d}\end{array}$ \\
\hline ALT (U/l) & $27-87 \mathrm{~b}$ & $14-50 \mathrm{~b}$ & $11-34 \mathrm{a}$ & $\begin{array}{l}15-108 \mathrm{c} \\
22-66 \mathrm{~d}\end{array}$ & $10-52 \mathrm{a}$ \\
\hline $\mathrm{AP}(\mathrm{U} / \mathrm{l})$ & $2152-7410 \mathrm{~b}$ & $\begin{array}{l}691-3249 c \\
832-1779 d\end{array}$ & $500-1905$ b & $375-1592 \mathrm{~b}$ & $285-1397$ a \\
\hline GGT (U/l) & $30-123 b$ & $19-62 \mathrm{~b}$ & $18-61 \mathrm{~b}$ & $\begin{array}{l}8-41 \mathrm{c} \\
22-39 \mathrm{~d}\end{array}$ & $16-43 \mathrm{a}$ \\
\hline $\mathrm{TP}(\mathrm{g} / \mathrm{l})$ & $31-77$ a & $39-66$ a & $44-67$ a & $33-63 \mathrm{a}$ & $36-68 \mathrm{a}$ \\
\hline $\operatorname{Alb}(\mathrm{g} / \mathrm{l})$ & $7-15 a$ & $24-40$ a & $26-39$ a & $20-39$ a & $22-42$ a \\
\hline Urea $(\mathrm{mmol} / \mathrm{l})$ & $\begin{array}{l}1.4-11.5 \mathrm{c} \\
2.9-9.6 \mathrm{~d}\end{array}$ & $0.6-4.8 \mathrm{~b}$ & $1.2-5.4 \mathrm{~b}$ & $0.5-3.8 \mathrm{a}$ & $0.7-6.3 \mathrm{~b}$ \\
\hline Creat $(\mu \mathrm{mol} / \mathrm{l})$ & $\begin{array}{l}53-96 \mathrm{c} \\
56-88 \mathrm{~d}\end{array}$ & $63-110 a$ & $62-100 a$ & $\begin{array}{l}73-111 \mathrm{c} \\
80-110 \mathrm{~d}\end{array}$ & $65-111$ a \\
\hline $\mathrm{TB}(\mu \mathrm{mol} / \mathrm{l})$ & $\begin{array}{l}0-16 c \\
2-10 d\end{array}$ & $\begin{array}{l}0-9 \mathrm{c} \\
1-7 \mathrm{~d}\end{array}$ & $\begin{array}{l}0-10 c \\
2-7 d\end{array}$ & $\begin{array}{l}0-7 \mathrm{c} \\
1-4 \mathrm{~d}\end{array}$ & $\begin{array}{l}0-16 \mathrm{c} \\
1-5 \mathrm{~d}\end{array}$ \\
\hline Chol (mmol/l) & $1.0-3.5 \mathrm{~b}$ & $2.0-6.5 \mathrm{~b}$ & $\begin{array}{l}2.1-8.0 \mathrm{c} \\
2.5-5.0 \mathrm{~d}\end{array}$ & $1.6-4.3 \mathrm{a}$ & $1.8-5.4 \mathrm{~b}$ \\
\hline Trig (mmol/l) & $0.3-4.1 \mathrm{~b}$ & $0.4-2.5 \mathrm{~b}$ & $\begin{array}{l}0.2-2.4 \mathrm{c} \\
0.6-1.4 \mathrm{~d}\end{array}$ & $\begin{array}{l}0.3-3.0 \mathrm{c} \\
0.4-1.7 \mathrm{~d}\end{array}$ & $0.3-1.6 \mathrm{~b}$ \\
\hline FFA (mmol/l) & $\begin{array}{l}0.2-1.1 \mathrm{c} \\
0.2-0.7 \mathrm{~d}\end{array}$ & $\begin{array}{l}0.1-1.3 \mathrm{c} \\
0.3-0.9 \mathrm{~d}\end{array}$ & $\begin{array}{l}0.2-1.1 \mathrm{c} \\
0.2-0.7 \mathrm{~d}\end{array}$ & $\begin{array}{l}0.1-1.5 \mathrm{c} \\
0.1-0.8 \mathrm{~d}\end{array}$ & $\begin{array}{l}0.1-0.8 \mathrm{c} \\
0.1-0.7 \mathrm{~d}\end{array}$ \\
\hline Glu (mmol/l) & $2.6-7.4 \mathrm{a}$ & $5.7-8.1 \mathrm{~b}$ & $5.0-8.4 \mathrm{a}$ & $5.1-8.3 \mathrm{a}$ & $4.7-8.6 \mathrm{a}$ \\
\hline $\mathrm{P}(\mathrm{mmol} / \mathrm{l})$ & $\begin{array}{l}0.8-2.9 \mathrm{c} \\
1.1-2.5 \mathrm{~d}\end{array}$ & $2.5-4.2 \mathrm{a}$ & $2.5-4.1 \mathrm{~b}$ & $2.6-4.0 \mathrm{a}$ & $2.4-4.0 \mathrm{a}$ \\
\hline $\mathrm{Ca}(\mathrm{mmol} / \mathrm{l})$ & $\begin{array}{l}2.1-3.2 \mathrm{c} \\
2.4-2.9 \mathrm{~d}\end{array}$ & $\begin{array}{l}2.6-3.3 \mathrm{c} \\
2.6-3.1 \mathrm{~d}\end{array}$ & $2.5-3.2 \mathrm{a}$ & $\begin{array}{l}2.4-3.3 \mathrm{c} \\
2.5-3.0 \mathrm{~d}\end{array}$ & $2.4-3.2 \mathrm{a}$ \\
\hline $\mathrm{Mg}(\mathrm{mmol} / \mathrm{l})$ & $0.59-1.03 \mathrm{a}$ & $0.69-1.26 \mathrm{a}$ & $0.68-1.19$ a & $0.59-1.08 \mathrm{a}$ & $0.67-1.14 \mathrm{a}$ \\
\hline $\mathrm{Na}(\mathrm{mmol} / \mathrm{l})$ & $\begin{array}{l}118-147 \mathrm{c} \\
134-145 \mathrm{~d}\end{array}$ & $\begin{array}{l}135-163 c \\
137-148 d\end{array}$ & $\begin{array}{l}119-154 \mathrm{c} \\
129-143 \mathrm{~d}\end{array}$ & $\begin{array}{l}132-152 \mathrm{c} \\
138-148 \mathrm{~d}\end{array}$ & $130-152$ a \\
\hline $\mathrm{K}(\mathrm{mmol} / \mathrm{l})$ & $2.5-5.7 \mathrm{a}$ & $3.4-5.5 \mathrm{a}$ & $\begin{array}{l}3.7-5.8 \mathrm{c} \\
3.8-5.2 \mathrm{~d}\end{array}$ & $3.4-5.1 \mathrm{a}$ & $3.5-5.6 \mathrm{~b}$ \\
\hline $\mathrm{Cl}(\mathrm{mmol} / \mathrm{l})$ & $\begin{array}{l}95-120 \mathrm{c} \\
102-114 \mathrm{~d}\end{array}$ & $\begin{array}{l}99-132 \mathrm{c} \\
102-116 \mathrm{~d}\end{array}$ & $93-117$ a & $\begin{array}{l}99-124 \mathrm{c} \\
101-114 \mathrm{~d}\end{array}$ & $98-114 a$ \\
\hline $\mathrm{Fe}(\mu \mathrm{mol} / 1)$ & $\begin{array}{l}4-24 c \\
5-17 d\end{array}$ & $\begin{array}{l}5-83 c \\
8-65 d\end{array}$ & $\begin{array}{l}3-67 c \\
5-12 d\end{array}$ & $8-89 \mathrm{~b}$ & $4-82 \mathrm{~b}$ \\
\hline TIBC $(\mu \mathrm{mol} / 1)$ & $16-63 \mathrm{~b}$ & $59-141 \mathrm{~b}$ & $104-188$ a & $44-141$ a & $74-181$ a \\
\hline
\end{tabular}

$\mathrm{a}=$ Gaussian distributed.

$\mathrm{b}=$ Gaussian distributed when logarithmically transformed.

$c=2.5$ th and 97.5 th percentiles.

$\mathrm{d}=10$ th and 90 th percentiles. 
viding a large number of measurements are taken, this gives a good assumption (Lumsden \& Müllen 1978). In the present trial, the number of animals joining the groups was fairly restricted, and the consequent rather few outliers will affect the percentiles. For most of the parameters, however, the plots showed a near Gaussian distribution, and the 97.5th and 2.5th percentiles were very close to what would have been the reference limits if Mean $\pm 1.96 \mathrm{SD}$ had been used. When the 90th and 10th percentiles were used in such cases, the normal reference range became more narrow and excluded values on both sides, resulting in more false positive values being found in the population.

The average elevation of TIBC and decrease in serum $\mathrm{Fe}$ in the anaemic piglets found in the present study on days 21 and 35 are in agreement with other studies (Furugouri 1975, Dallman 1986). Serum Fe was, however, very high in some severely anaemic piglets on day 21 , possibly due to these piglets having ingested iron before a satisfactory rise in HGB had occurred. This indicates that serum Fe levels do not always reflect the levels of HGB or iron stores.

The average weaning weight of the anaemic piglets in the present study was $10.75 \mathrm{~kg}$, which must be considered to be high. The "normal" piglets weighed, however, $12.20 \mathrm{~kg}$, reflecting the high growth capacity of Norwegian Landrace piglets. The $180 \mathrm{mg}$ iron injected on day 1 will cover the iron demands in piglets showing this rate of weight gain for only about 14 days when sow's milk is the sole source of food (Egeli 1998). Although the piglets had access to extra iron and pelleted feed, the relatively low HGB values found on days 21 and 35 in the injected piglets, seen together with results from another study performed by the authors, indicate that the iron reserves at these times after birth were beginning to be depleted (Egeli \& Framstad 1998a). The very wide reference range for serum Fe in the "normal group" may also indicate that iron reserves are beginning to be depleted, despite still satisfactorily high HGB levels. The reference ranges for serum Fe and TIBC, are, like the haematological parameters, affected by the administration of iron to the piglets. The administration of more iron, or less iron, or poorer weight gain, would probably have influenced the reference ranges for these parameters. Although giving an indication of the iron reserves, it therefore seems inappropriate to speak of "normality" in such cases.

When the plots were skewed to the right, the 90th percentiles were quite different from the 97.5th percentiles. This was particularly the case for GD on days 1 and 21 . The samples with very high GD were measured twice with the same results, which could not be explained by illness, lipaemia or haemolysis. This makes it nearly impossible to evaluate GD in a few weeks old piglets. The results of GD are probably uncertain and are therefore not shown in Table 5.

Some of the enzyme data were also moderately skewed, and some showed great variation, giving a wide reference range. The standard deviation of CK and LD were, for instance, very high, and the value of these enzymes as a diagnostic tool in piglets is therefore probably limited. The risk of contaminating blood during sampling involving muscle tissue damage may explain some of the variation. $\mathrm{CK}$ and LD are also unstable by storage. They are therefore not shown in Table 5.

AP decreased with age in both the mean value and standard deviation found in the present study. This is also described in the literature and reflects osteoblast activity in growing animals (Kramer 1989, Framstad et al. 1991).

The lower reference limit for TB was estimated to be zero. The analyser does not give results to decimals for this parameter, thereby giving this seemingly unphysiological value. Shortly after birth the high level in TB could be explained by 
shortened lifespan of foetal erythrocytes, although accelerated breakdown in piglets is not as common as in human children, where the foetal haemoglobin is replaced after birth (Harvey 1997).

The birth process, and adaptation from an intrauterine to an extra-uterine existence with all its associated hormonal, metabolic and circulatory changes, could affect clinical biochemistry in piglets during the first days of life. Liver function is not fully developed immediately after birth, and the production of proteins is therefore restricted. This means that serum values of TP, Alb and TIBC in piglets immediately after birth will be low (Furugouri 1975, Kaneko 1989). The diet of new-born piglets may influence clinical biochemistry in regard to protein, fat and carbohydrate metabolites. Gluc, Trig, FFA and Chol have all been found to increase after colostrum consumption (Bengtsson et al. 1969, Brenner \& Gürtler 1977, Mersmann et al. 1979). The increase in TP after colostrum consumption is explained by globulin absorption (Kaneko 1989). This seems to be in agreement with the present study, in which the average TP on day 1 , although showing a higher SD, was at a level found later in the preweaning period, while Alb was still much lower on day 1 than later on. As the piglets sampled on day 1 varied in age from 12 to $36 \mathrm{~h}$, the consumption of colostrum and milk would have, varied to some extent between piglets. The wider reference ranges found for many parameters on day 1 than later in the preweaning period may be explained by differences between piglets in colostrum consumption, hence if piglets had been fasted before blood sampling some of those variations could have been minimised or eliminated. Fastening of the one day old piglets would, however, not be representative or desired in most research projects or under ordinary commercial conditions. Blood sampling on day 1 at the same time after birth for all ani- mals could also have eliminated some variation, but was not practical applicable. A fixed time on the day, the mornings, were then chosen. Also stress factors such as a cold environment and competition for feed/fighting, might have an interfering effect on the first day of life. The iron stores in piglets are very small, as is the iron content in sow's milk (Venn et al. 1947). The values for serum Fe and TIBC in the present study were, as expected, very low on day 1 . Tollersrud \& Baustad (1970) investigated the enzymes AST, ALT and LD in piglets after birth and concluded that metabolic changes following parturition rather than colostrum absorption were responsible for the higher enzyme levels found in one day old piglets compared with new-born. Grün \& Ix (1973) found a rise in AST, ALT and LD in piglets from birth to about 12-14 $\mathrm{h}$ after parturition, and thereafter a decrease over the first week to the initial level found just after parturition. Tumbleson et al. (1972) found a sharp increase 12-24 $\mathrm{h}$ after birth in TP, Gluc, Urea, LD and AST, and thereafter a decrease in Urea and AST; whereas there was a gradual increase in $\mathrm{Alb}, \mathrm{Chol}$ and $\mathrm{P}$ during the first week. None of the above findings seem to be in conflict with our present results.

Many clinical biochemical parameters seem to vary between piglets and adult pigs. This could be explained by differences in diet, or the high growth rate of piglets compared to adults. $M c$ Clellan et al. (1966) considered, for instance, that the higher $\mathbf{P}$ found in young miniature swine could be explained by the growth of the bones. The diet has also been found to affect $\mathbf{P}$ (Miller et al. 1964, Coalson et al. 1972). This probably explains the elevated reference range for $P$ determined in the present study in piglets on days 21 and 35 compared to Norwegian Landrace sows (Framstad et al. 1991). Ca levels seemed, however, to be unaffected by age, the reference range in piglets in the present study 
being nearly the same as in the Norwegian Landrace sows.

The anaemic piglets were compared to the "normal" piglets on days 21 and 35. Although severely anaemic over a prolonged period, with resulting impairment of growth and lowering of the leukocyte count, surprisingly small changes were found in the clinical biochemistry. Neither weight gain nor WBC were significantly affected until some weeks after the anaemia had developed. Such a long lag period did not seem to be the case for clinical biochemical parameters, the greatest differences between groups being found when the piglets were most anaemic. A decrease in the erythrocyte count and impaired ability to transport $0_{2}$ affect many physiological processes, severe anaemia, for instance, affecting the physiology of blood circulation, fluid balance, blood-acid/base, osmolarity of the blood, and kidney function. The oxygen supply to different organs will also be disturbed, and hypoxia may occur. Moreover, when the anaemia is due to an iron deficiency, as in the present trial, direct effects of iron deficiency will complicate the picture. Iron is essential for normal cell function and is a component of many enzymes (Smith 1989, Dallman 1986). Iron deficiency causes a chronic anaemia, and various mechanisms will therefore be activated to compensate any adverse physiological changes, and to maintain homeostasis. It is beyond the scope of this study to discuss the different physiological changes which might influence the clinical biochemical parameters in iron deficiency anaemic piglets. Further investigation is needed to explain some of the mechanisms which might be involved. Electrolyte levels seem, for example, to be affected by the presence of an iron deficiency anaemia. In the present study, $\mathrm{Na}$ and $\mathrm{Cl}$ were significantly lower in the anaemic piglets on day 21. Coulter \& Swenson (1973) also found significantly lower plasma $\mathrm{Na}$ and numerically lower $\mathrm{Cl}$ in iron-deficient feeder piglets. Carlson (1989) asserted that changes in $\mathrm{Na}$ and $\mathrm{Cl}$ levels in the same direction (i.e. both up or both down) are caused by changes in blood volume, while dissimilar changes may indicate an acid-base disturbance. Schlerca (1981) found a metabolic acidosis in iron-deficient anaemic piglets. Metabolic acidosis caused by the hypoxic condition in tissues is very likely present in anaemic piglets. Kaneko (1989) suggested that severe anaemia in animals might result in hyperventilation with consequent respiratory alkalosis. The degree and duration of the iron-deficiency anaemia, and together with differences in the piglets' physical activity, may give different physiological manifestations of the anaemia. In the present study, it was impossible to evaluate the exact mechanisms involved, because no information on the acid/base balance was available.

Although the anaemic piglets had statistically significantly lower AST, ALT, AP and LD on day 21 than "normal" piglets, the differences were small and not of diagnostic significance. Lower AST, ALT and LD levels might have been caused by a corresponding low tissue level of those enzymes during an iron deficiency.

Ku et al. (1983) found that the administration of 100-200 mg iron as iron-dextran had no effect on serum minerals other than Fe. The relatively long period elapsing between the injection of iron and blood sampling in the present study would also seem to indicate that it was the anaemic condition per se, which led to the differences in clinical biochemical parameters between the groups.

Although present, the differences between mean values and reference ranges in anaemic and "normal" piglets were surprisingly small. Nevertheless, they did indicate that anaemia might affect some of the parameters, a factor. which should be taken into account when evaluating piglets in the preweaning period. 


\section{Acknowledgements}

The authors wish to thank the staff of the Central Laboratory, Department of Physiology, Biochemistry and Nutrition, Norwegian College of Veterinary Medicine for technical assistance.

\section{References}

Agricultural Research Council: The nutrient requirements of farm livestock. London. 1967, Pigs.

Baustad B: Forsøk med perorale jerntilskudd til smågris. (Studies on peroral iron supplementation in piglets). Medlemsbl. norske Veterinær Foren. 1969, 21, 253-262. (In Norwegian).

Bengtsson G, Gentz J, Hakkarainen J, Hellström R, Persson B: Plasma levels of FFA, glycerol, $\beta$-hydroxybutyrate and blood glucose during the postnatal development of the pig. J. Nutr. 1969, 97, 311-315.

Brenner KV, Gürtler H: Die Konzentration an Kortisol, Glukose und freien Fettsäuren im Blutplasma bei Schweinen in Abhängigkeit vom Alter sowie bei Sauen im Zeitraum der Geburt. (Concentrations of cortisone, glucose, and free fatty acids in blood plasma of swine, depending on age, and in sows close to farrowing.) Arch. exp. Vet.-Med. 1977, 31, 741-747.

Carlson GP: Fluid, electrolyte, and acid-base balance. In: Kaneko JJ (ed.) Clinical biochemistry of domestic animals. 4th ed. Academic Press. San Diego, California. 1989, 543-575.

Coalson JA, Maxwell CV, Hillier JC, Washam RD, Nelson EC: Calcium and phosphorus requirements of young pigs reared under controlled environmental conditions. J. Anim. Sci. 1972, 35, 1194-1200.

Coulter DB, Swenson MJ: Plasmatic and erythrocytic electrolytes in iron-deficiency anemia of pigs (SUS SCROFA). Comp. Biochem. Physiol. 1973, 44A, 461-466.

Dallman PR: Biochemical basis for the manifestations of iron deficiency. Ann. Rev. Nutr. 1986, 6, 13-40.

Egeli $A K$ : Iron deficiency anaemia in piglets. $\mathrm{PhD}$ thesis, Norwegian College of Veterinary Medicine, Oslo, Norway. 1998.

Egeli AK, Framstad T: Evaluation of the efficacy of perorally administered glutamic acid-chelated iron and iron-dextran injected subcutaneously in Duroc and Norwegian Landrace piglets. J. Vet. Med. A, 1998a, 45, 1-000
Egeli AK, Framstad T: Effect of an oral starter dose of iron on haematology and weight gain in piglets having voluntary access to glutamic acidchelated iron solution. Acta vet. scand. 1998b.

Egeli AK, Framstad T, Grønningen D: The effect of peroral administration of amino acid-chelated iron to pregnant sows in preventing sow and piglet anaemia. Acta Vet. Scand. 1998c, 39, 1.

Farver TB: Concepts of normality in clinical biochemistry. In: Kaneko JJ (ed.) Clinical biochemistry of domestic animals. 4th ed. Academic Press. San Diego, 1989, 1-20.

Framstad T, Sjaastad $\varnothing V$, Aass $R$ : Blodprøvetaking på gris. (Blood sampling in pigs) Norsk Vet.-T. 1988, 100, 265-273. (In Norwegian).

Framstad T, Havre GN, Morberg H: Effekt av lagring, separering og heparin på klinisk-kjemiske analyseresultater av griseblod. (The effect of storage, separation and use of heparin on the clinical biochemical analysis of pig blood) Norsk Vet.-T. 1989, 101, 237-243. (In Norwegian).

Framstad T, Morberg H, Aass RA: Klinisk-kjemiske analyser av griseblod. Referanseområder for purker. (Clinical biochemical analyses of pig blood. Reference ranges for sows) Norsk Vet.-T. 1991, 103, 807-815. (In Norwegian).

Friendship RM, Lumsden JH, McMillan I, Wilson $M R$ : Hematology and biochemistry reference values for Ontario swine. Canad. J. comp. Med. 1984, 48, 390-393.

Furugouri $K$ : Characteristic aspects of iron metabolism in piglets. Jap. agric. Res. Q. 1975, 9, 171-176.

Gainer JH, Guarnieri J, Das NK: Neutropenia and anemia in the iron deficient baby pig. Calif. Vet. $1985,1,18-41$.

Glawischnig Von E, Schlerka G, Schuller W, Baumgartner $W$ : Arbeitswerte in der laboratoriumsdiagnostik beim schwein. (Working values for laboratory diagnosis in pigs.) Wien. tierärztl. Mschr. 1977, 64, 341-346.

Groth Von W, Kalchreuter S, Hahn R: Die Einflüsse der Rasse, des Alters, der Jahreszeit und der Umstallung in die Besamungsstation auf Enzymaktivitäten, Mineralstoff- und Harnstoffkonzentratione im Blutplasma von Besamungsebern. (Influence of breed, age, season and change of housing on enzyme activity, and mineral and urea concentrations in blood plasma of boars) 1 Teil. Tierärztl. Umsch. 1986, 41, 652-658.

Groth Von W, Kalchreuter S, Hahn R: Die Einflüsse der Rasse, des Alters, der Jahreszeit und der Um- 
stallung in die Besamungsstation auf Enzymaktivitäten, Mineralstoff- und Harnstoffkonzentratione im Blutplasma von Besamungsebern. (Influence of breed, age, season and change of housing on enzyme activity, and mineral and urea concentrations in blood plasma of boars) Teil 2 . Tierärztl Umsch. 1986, 41, 778-787.

Grün Von E, U. Ix: Serumenzyme bei neugeborenen Tieren. 2. Mitt.: Verhalten bei neugeborenen Ferkeln. (Serum enzymes in new-born animals. 2nd communication: Behaviour in new-born piglets.) Mh. Vet.-Med. 1973, 28, 705-712.

Harvey JW: The erythrocyte: Physiology, Metabolism, and Biochemical Disorders. In: Kaneko JJ, Harvey JW, Bruss ML (ed.) Clinical biochemistry of domestic animals. 5th ed. Academic Press. San Diego, 1997, 157-203.

Kaneko JJ: Appendix VII: Normal blood analysis values in large animals. In: Kaneko JJ (ed.) Clinical biochemistry of domestic animals. 4th ed. Academic Press. San Diego, California. 1989, 886-891.

Kaneko JJ: Serum proteins and the dysproteinemias. In: Kaneko JJ (ed.) Clinical biochemistry of domestic animals. 4th ed. Academic Press. San Diego, 1989, 142-165.

Kramer JW: Clinical enzymology. In: Kaneko JJ (ed.) Clinical biochemistry of domestic animals. 4th ed. Academic Press. San Diego, 1989, 338363.

$K u P K$, Miller ER, Ullrey DE: Effect of parenteral iron on serum electrolytes of the baby pig. J. Anim. Sci. 1983, 57, 638-644.

Lumsden JH, Mullen K: On establishing reference values. Canad. J. comp. Med. 1978, 42, 293-301.

McClellan RO, Vogt GS, Ragan HA: Age-related changes in hematological and serum biochemical parameters in miniature swine. In: Swine in biomedical research. Frayn printing, Seattle. 1966, 597-610.

Mersmann HJ, Arakelian MC, Brown LJ: Plasma lipids in neonatal and growing swine. J. Anim. Sci. 1979, 48, 554-558.

Miller ER, Ullrey DE, Zutaut CL, Betty, Baltzer V, Schmidt DA, Hoefer JA, Luecke RW: Phosphorus requirement of the baby pig. J. Nutr. 1964, 82,.34-40.

Reese DE, Peo ER, Lewis AJ, Hogg A: Serum chemical values of gestating and lactating swine: Reference values. Amer. J. Vet. Res. 1984, 45, 978980.

Schlerka Von G, Köfer J, Baumgartner W, Schuh M: Verlaufsuntersuchungen über die Blutgase und den Säure-Basen-Haushalt mit Bestimmung von Hämoglobin und Hämatokrit bei Ferkeln. (Follow up studies on blood gases, acid-base-relationship, hemoglobin and hematocrit in blood from piglets. 2nd communication: phase from birth to weaning.) Dtsch. Tierärztl. Wschr. 1981, 88, 50-53.

Smith JE: Iron metabolism and its diseases. In: Kaneko JJ (ed.) Clinical biochemistry of domestic animals. 4th ed. Academic Press. San Diego, 1989, 256-273.

Tewes H, Steinbach J, Smidt D: Investigations on the blood composition of sows during the reproductive cycle. II. Blood changes during pregnancy. Zuchthyg. 1979, 14, 111-116.

Tewes H, Steinbach J, Smidt D: Investigations on the blood composition of sows during the reproductive cycle. Blood changes during lactation. Zuchthyg. 1979, 14, 111-116.

Tollersrud S, Baustad B: Serum enzyme activity of new-born calves, pigs, and lambs. Acta Vet. Scand. 1970, 11, 525-535.

Tumbleson ME, Hutcheson DP, Fogg TJ: Serum biochemical values of fetal and neonatal crossbred swine. Technicon International Congress (1970, New York) Advances in automated analysis. Futura Pub. Co, Mount Kisco, New York. 1972, 149-156.

Tumbleson ME, Schmidt DA, Scholl E: Hematology and clinical chemistry. In Diseases of swine. A.D. Leman (ed.) 6th ed. Ames, Iowa, The Iowa State University Press. 1986, 27-44.

Ullrey DE, Miller ER, Brent BE, Bradley BL, Hoefer $J A$ : Swine hematology from birth to maturity. IV. Serum calcium, magnesium, sodium, potassium, copper, zink and inorganic phosphorus. J. Anim. Sci. 1967, 26, 1024-1029.

van Kempen GJM: Avoid iron deficiency in piglets. Pigs. 1987, 3, 10-11.

Venn JAJ, McCance RA, Widdowson EM: Iron metabolism in piglet anaemia. J. comp. Path. 1947, 57, 314-325.

Wilson GDA, Harvey $D G$, Snook $C R$ : A review of factors affecting blood biochemistry in the pig. Brit. Vet. J. 1972, 128, 596-609.

\section{Sammendrag}

Klinisk biokjemi, hematologi og vekt hos grisunger.

Denne undersøkelsen gir referanseområder hos en (dag 1), 21 og 35 dager gamle griser for vanlig brukte 
klinisk biokjemiske parametre hos griser. Gjennomsnittet og standardavviket ble også estimert for kroppsvekt, hematologiske og klinisk biokjemiske parametre på disse dager.

Grisungene ble delt $\mathrm{i}$ to undersøkelses grupper $\mathrm{i}$ henhold til hemoglobin konsentrasjon $\leq 80 \mathrm{~g} / \mathrm{l}$ ("anemisk gruppe") eller $>80 \mathrm{~g} / 1$ ("normal gruppe") på dag 14, 21 og 28. På dag 21 and 35 ble "anemisk gruppe" sammenlignet med "normal gruppe".

Mange av de klinisk biokjemiske parametrene ble påvirket av alder. Noen av enzymene hadde høye gjennomsnittsverdier og vide referanseområder hos grisunger, spesielt på dag 1, sammenlignet med referanseområder for purker gitt i literaturen. Referanseområdene for noen av de metabolske parametrene var videre på dag 1 enn seinere $\mathrm{i}$ pattegris perioden. Referanseverdiene for albumin, serum jern og total jernbindings kapasitet var imidlertid lavere og referanseområdene var smalere på dag 1 . Relativt høye verdier av fosfor må bli ansett som normalt på dag 21 og 35 sammenlignet med voksne griser. De andre mineralene så ut til å være upåvirket av alder, men noen var påvirket av anemi. De anemiske grisungene hadde lavere gjennomsnitt serum jern, men høyere total jernbindings kapasitet enn de normale grisungene på dag 21 og 35 . Variasjonen mellom grisungene forårsaket imidlertid videre referanseområder, som indikerer restriksjoner $i$ disse parametrenes nytte i å påvise jernmangel hos grisunger.

Kroppsvekten og leukocyttene var signifikant lavere i den "anemiske gruppen" enn den "normale gruppen" på dag 35, men den største forskjellen i klinisk biokjemiske parametre mellom gruppene ble funnet på dag 21, da grisungene i den "anemiske gruppen" var mest anemiske. Selv om disse grisungene led av alvorlig jernmangel anemi, var bare noen få av de klinisk biokjemiske parametrene påvirket, og forskjellen mellom gruppene var for det meste små.

(Received October 20, 1997; accepted May 10, 1998).

Reprints may be obtained from: A.K. Egeli, Department of Reproduction and Forensic Medicine, Norwegian College of Veterinary Medicine, POB. 8146 Dep. N-0033 Oslo, Norway. E-mail: a.k.egeli@veths.no, tel: +47229648 74, fax: +4722597083. 
